\title{
Evaluation of Different Crop Sequence Production Potential, Economics and Nutrient Balance under New Alluvial Situation Of NEPZ
}

\author{
Dhiman Mukherjee* \\ *Department of Agronomy, Directorate of Research, Bidhan Chandra KrishiViswavidyalaya.
}

Received: September 19, 2016; Accepted: October 18, 2016; Published: November 1, 2016

*Corresponding author: Dhiman Mukherjee, Department of Agronomy, Directorate of Research, Bidhan Chandra Krishi Viswavidyalaya, Kalyani-741235, West Bengal, Officer incharge of AICRP on Wheat and Barley Improvement Project, BCKV, Kalyani. E-mail: dhiman_mukherjee@ yahoo.co.in

\begin{abstract}
A field experiment was conducted during 2014-16 at Kalyani, under the aegis of Bidhan Chandra Krishi Viswavidayalayathe to evaluate the most profitable and efficient cropping systems for indogangetic belt of west Bengal. Treatment comprised of 14 cropping sequence system tested in randomized block design with three replications. For comparison between crop sequences, the yields of all crop sequences were converted into rice equivalent on price basis. With various treatments, more rice equivalent yield was observed with rice-mung sequence $(5897 \mathrm{~kg} / \mathrm{ha})$, and was significantly higher than rest of the sequence during kharif season and was at par with the maize-wheat (5868 kg/ha), chilly- wheat (5694 kg/ha) and maizecabbage (5503 kg/ha) system. This tested crop sequence resulted in $21.9,21.3,17.7$ and $13.7 \%$ more grain yield over traditional practice of rice- wheat system, which is most dominant in this region. However, during Rabi season rice- potato ( $6613 \mathrm{~kg} / \mathrm{ha})$, gave significantly more economic yield compare to all other cropping pattern. This sequence resulted in $128.1 \%$ more rice equivalent grain yield over traditional practice of rice- wheat system. Further, rice - cauliflower sequence gave the highest net return (Rs. 97.58 thousand/ha), followed by rice - chickpea (Rs. 88.69 thousand/ha) and rice - mung (Rs. 84.36 thousand/ha). Higher benefit: cost ratio was obtained from ricemung (2.23) and was just followed by chilly -wheat (2.22) and ricecauliflower (2.19) cropping sequence. Present work revealed that, productivity, profitability and sustainable yield index were higher under rice - cauliflower and rice - mung cropping sequence then the traditional rice -wheat sequence. Further, overall nutrient mining by this system was quite low compared to other sequences and suitable under this zone.
\end{abstract}

Keywords: Cropping Sequence; Nutrient Balance Sheet; Profitability; SYI; Yield;

\section{Introduction}

Food security is one of the most important challenges in present era of agriculture production system. Rice, maize, and wheat are major cereals contributing to food security and income in South Asia. These crops are grown either as a monoculture or in rotations in tropical and sub-tropical environments of India and its adjoining state. In the irrigated and favorable rainfed lowland areas, rice-rice, rice-wheat, and rice-maize are the predominant cropping systems. Rice-rice is common in tropical climate with distinct dry and wet seasons such as in South India, and in sub-tropical areas with mild cool winter climate such as in Bangladesh, Eastern India, and Eastern Nepal. Rice-wheat systems are extensive in the sub-tropical areas of the Indo-Gangetic Plains (IGP) of Bangladesh, India, Nepal, and Pakistan while rice - maize systems exist in all climate ranging from tropical to sub tropical to warm temperate. Rice-maize systems, however, are less extensive as compared to rice - wheat or rice - rice if total area under these cereal systems is considered. Long conventional cropping system of rice - wheat is being followed in the most part of the India since more than three decades, and its result in term of production is quite low. This becomes a vital challenge for food security of a common people (Mukherjee, 2015). The productivity trend of rice-wheat system is consistently declining in most of area and as such the income from this system is hardly sufficient for its continuance on sustainable basis. The exhaustive nature of cereal based cropping sequence may be the reason for decrease in yields and farmer benefit: cost ratio (Mukherjee, 2015 a). Besides, continuously following the same system in long term, leads to adverse effect on soil conditions, and it ultimately reduce the productivity of the system. Further, the inclusion of crops like oilseed, pulse and vegetable will improve the economic condition of the farmers owing to higher price and higher volume of their main and byproducts. Due to favorable influence of legumes on soil health, the legume and oilseed based alternate cropping system may be economically viable and give sustained profitable production (Mukherjee, 2014). Singh and Verma (1998) also reported beneficial effect of inclusion of pulses, oilseeds and vegetables in the system than cereals after cereals. In addition legume has favorable impact on the soil fertility and help in increasing the yield of the succeeding crop in sequence [3]. A basket of resource conserving technologies and suitable crop under different zone is being developed and made available to farmers and scientist community for experimentation and 
adoption. However, their relevance to farmer economic benefit is quite dismal. In view of these facts, the present experiment was carried out to evaluate most economically viable, feasible, sustainable crop sequence and their relative nutrient balance in the soil under new alluvial zone of West Bengal.

\section{Materials And Methods}

Present investigation was conducted under the aegis of Bidhan Chandra Krishi Viswavidyalaya during 2014-15 and 2015-16 in Kalyani (Majherchar). The farm is situated at approximately $22^{\circ} 56^{\prime} \mathrm{N}$ latitude and $88^{\circ} 32^{\prime} \mathrm{E}$ longitude with an average altitude of $9.75 \mathrm{~m}$ above Mean Sea Level (MSL). The soil of the experimental field was loamy in texture and almost neutral in reaction having $\mathrm{pH} 7.1$, organic carbon $0.46 \%$, available nitrogen $236.3 \mathrm{~kg}$, available phosphorus 22.1 and available potassium $239 \mathrm{~kg} / \mathrm{ha}$. Treatment comprised of 14 cropping sequence system (Table 1) with following variety viz. Swarnadhan for rice, UPAS 120 for pigeon pea, local cultivar for maize, DBW-39 for wheat, Radhe for chickpea, B-54 for mustard, Sarda for blackgram, JRO -78 for jute, Kufri chandramukhi for potato, Bhagyra lakshmi for chilly, Samrat for Mung, Dania for cauliflower and Pusa Drum head for cabbage. Crop included in different sequences were raised with recommended agronomic practices. The treatments were tested in randomized block design with three replications. For comparison between crop sequences, the yields of all crop sequences were converted into rice equivalent on price basis [11]. Land use efficiency, production efficiency ( $\mathrm{kg} / \mathrm{ha} /$ day) and other economic pattern were measured as per standard procedure [9]. The economics and rice equivalent yield were computed at prevailing market rates during 2015-16 of different commodities. The crop sequence was evaluated based on a sustainability index [10]. The Nitrogen, P and $\mathrm{K}$ were applied through urea single super phosphate and muriate of potash, respectively. In case of potato instead of muriate of potash, potassium sulphate was applied. Initial soil status and plant sample under different cropping sequence was collected and analyzed following the standard procedure [1, 2]. Available phosphorous was determined by Olsen's method as outlined by Jackson (1973), using spectrophotometer (660 nm wave length). Available potassium was extracted with neutral normal ammonium acetate and the content of $\mathrm{K}$ in the solution was estimated by flame photometer. The experimental data were analyzed statistically by applying the technique of analysis of variance (ANOVA) prescribed for the design to test the significance of overall difference among treatments by the $\mathrm{F}$ test and conclusions were drawn at $5 \%$ probability level. Benefit: cost ratio (B: C) was obtained by dividing the gross income with cost of cultivation. The effect of treatments was evaluated on pooled analysis basis.

\section{Results And Discussion}

\section{Rice equivalent yield}

Crop yield response with respect to rice equivalent yield produced significant differences among tested sequence. Study revealed that, rice equivalent yield of rice-mung sequence (5897 $\mathrm{kg} / \mathrm{ha}$ ) was significantly higher than rest of the series during kharif season and showed parity with maize-wheat $(5868 \mathrm{~kg} /$ ha), chilly- wheat (5694 kg/ha) and maize-cabbage (5503 kg/ ha) system (Table 1). This tested crop sequence resulted in 21.9, 21.3, 17.7 and $13.7 \%$ more grain yield over traditional practice of rice- wheat system in this zone. However, during rabi season

Table 1: Rice equivalent yield, crop yield and duration of the cropping sequence (pooled data of two years).

\begin{tabular}{|c|c|c|c|c|c|c|c|c|c|}
\hline \multirow[t]{2}{*}{ Cropping sequence } & \multicolumn{3}{|c|}{$\begin{array}{l}\text { Rice equivalent yield } \\
\text { (kg/ha) }\end{array}$} & \multicolumn{3}{|c|}{$\begin{array}{l}\text { Crop yield } \\
\text { (kg/ha) }\end{array}$} & \multicolumn{3}{|c|}{$\begin{array}{c}\text { Duration of cropping system } \\
\text { (days) }\end{array}$} \\
\hline & Kharif & Rabi & Total & Kharif & Rabi & Total & Kharif & Rabi & Total \\
\hline Pigeon pea-wheat & 4299 & 3000 & 7299 & 1051 & 4125 & 5176 & 140 & 125 & 265 \\
\hline Black gram-wheat & 3328 & 3082 & 6410 & 1241 & 4239 & 5480 & 122 & 149 & 271 \\
\hline Rice-mung & 5897 & 3006 & 8903 & 5897 & 945 & 6842 & 130 & 92 & 222 \\
\hline Maize -wheat & 5868 & 2207 & 8075 & 4611 & 3035 & 7646 & 121 & 153 & 274 \\
\hline Maize-cabbage & 5503 & 4375 & 9878 & 4324 & 32084 & 36408 & 115 & 96 & 211 \\
\hline Rice-cauliflower & 3809 & 5162 & 8971 & 3809 & 22714 & 26523 & 122 & 93 & 215 \\
\hline Pigeonpea-jute & 5175 & 4303 & 9478 & 1265 & 2705 & 3970 & 161 & 131 & 292 \\
\hline Pigeonpea-jute & 5694 & 2632 & 8326 & 5011 & 3874 & 8885 & 130 & 145 & 275 \\
\hline Rice-chilli & 3475 & 4697 & 8172 & 3457 & 4134 & 7591 & 120 & 90 & 210 \\
\hline Rice-potato & 5142 & 6613 & 11755 & 5142 & 29100 & 34242 & 132 & 150 & 282 \\
\hline Maize-mustard & 5238 & 2687 & 7925 & 4116 & 1689 & 5805 & 115 & 141 & 256 \\
\hline Rice -chickpea & 5164 & 4954 & 10118 & 5164 & 2658 & 7822 & 130 & 140 & 270 \\
\hline Rice- mustard & 4733 & 2384 & 7117 & 4733 & 1499 & 6232 & 129 & 140 & 269 \\
\hline Rice-wheat & 4836 & 2899 & 7735 & 4836 & 3987 & 8823 & 131 & 126 & 257 \\
\hline $\mathrm{SEm} \pm$ & 158 & 318 & 410 & & & & & & \\
\hline $\mathrm{CD}(\mathrm{P}=0.05)$ & 660 & 890 & 1254 & & & & & & \\
\hline
\end{tabular}


rice- potato $(6613 \mathrm{~kg} / \mathrm{ha})$, gave significantly more economic yield compare to all other cropping prototype. This tested crop sequence resulted in $128.1 \%$, extra grain yield over traditional practice of rice- wheat system. Total yield of sequence more registered with the rice - potato $(11755 \mathrm{~kg} / \mathrm{ha})$ and statistically superior to rest of the tested treatments.

\section{Crop yield}

Amongst kharif crop rice gave the highest economic yield $(5897 \mathrm{~kg} / \mathrm{ha})$ in rice - mung sequence and was followed by rice $(5164 \mathrm{~kg} / \mathrm{ha})$ and chilly $(5011 \mathrm{~kg} / \mathrm{ha})$ in rice - chickpea and chilly - wheat rotation, respectively. Within Rabi season economic yield, cabbage shared of $32084 \mathrm{~kg} / \mathrm{ha}$ under maizecabbage sequence, and was followed by potato crop $(29100 \mathrm{~kg} /$ ha) under rice - potato rotation (Table 1). More crop yield was recorded with the maize-cabbage sequence and was followed by rice-potato and rice-cauliflower. However per unit production of cabbage was highest and was followed potato and cauliflower. Further study revealed that wheat production was more in black gram- wheat cropping system compared to other series of wheat based, presumably owing to beneficial effect of legumes on succeeding crop. Maximum duration of cropping system was recorded with pigeon pea-jute and was followed by rice-potato and maize-cabbage.

\section{LUE and SYI}

The highest land use efficiency (LUE) was recorded with pigeon pea-jute cropping sequence, because this sequence occupied the field for longest duration (292 days) and was followed by rice-potato (282 days) and maize-wheat (274 days) sequence. It was the lowest in maize - cabbage (211 days) (Table 2). Rice-cauliflower crop sequence was found to be highly sustainable, giving $94.83 \%$ sustainability yield index (SYI), followed by rice -chickpea (88.15\%) and rice-mung (84.90\%) sequence (Table 2). However, this was least recorded with pigeon pea - jute sequence (69.50\%). SYI of rice - wheat sequence (80.03) was quite low, this might be due to decline in soil organic matter and imbalance use of fertilizer and no $\mathrm{N}$ contribution from the atmosphere $\mathrm{N}$ - fixation [4].

\section{Economics}

Economic analysis indicated that rice - cauliflower sequence gave the highest net return (Rs. 97.58 thousand/ha), followed by rice - chickpea (Rs. 88.69 thousand/ha) and rice - mung (Rs. 84.36 thousand/ha). The results also revealed that higher benefit: cost ratio was obtained from rice-mung (2.23) and was just followed by chilly -wheat (2.22) and rice-cauliflower (2.19) cropping sequence (Table 2). However, least ratio was obtained with pigeon pea - jute (1.84) and rice - mustard (1.84) sequence. Rice-cauliflower, rice-chickpea - wheat and rice - mung sequence gave higher net returns of Rs. 97.58, 88.69 and 84.36 thousand /ha, respectively, over traditional rice - wheat rotation which was most dominating sequence in indo-gangetic belt of north eastern plain zone. Production efficiency in term of Rs/ha/day was highest with maize-cabbage (173.37), followed by rice cauliflower (123.36) and rice - potato (121.42) sequence, while profitability in terms of $\mathrm{kg} / \mathrm{ha} /$ day was the highest in the ricemung (380.12) sequence, this was followed by maize - cabbage sequence in the present investigation.

\section{Nutrient removal and balance sheet}

The highest removal of $\mathrm{N}$ was recorded in maize - cabbage cropping sequence $(702.3 \mathrm{~kg} / \mathrm{ha})$ and was significantly superior to other cropping sequence. This was followed by chilly - wheat

Table 2: Economics and other parameter under different cropping sequence (pooled data of two years).

\begin{tabular}{|c|c|c|c|c|c|c|c|c|}
\hline $\begin{array}{l}\text { Cropping } \\
\text { sequence }\end{array}$ & $\begin{array}{l}\text { Land use } \\
\text { efficiency } \\
\text { (LUE) } \\
(\%)\end{array}$ & $\begin{array}{c}\text { Cost of } \\
\text { cultivation } \\
\left(10^{3} \times \text { Rs./ha }\right)\end{array}$ & $\begin{array}{c}\text { Net return } \\
\left(10^{3} \times \text { Rs./ha }\right)\end{array}$ & $\begin{array}{l}\text { Benefit: cost } \\
\text { ratio }\end{array}$ & $\begin{array}{l}\text { Production } \\
\text { efficiency } \\
\text { (kg/ha/day) }\end{array}$ & $\begin{array}{l}\text { Profitability } \\
\text { (Rs./ha/day) }\end{array}$ & $\begin{array}{c}\text { Net profit or } \\
\text { loss over rice- } \\
\text { wheat system } \\
\left(10^{3} \times \text { Rs./ha) }\right.\end{array}$ & $\begin{array}{c}\text { Sustainable } \\
\text { yield index } \\
\text { (SYI) } \\
(\%)\end{array}$ \\
\hline Pigeon pea-wheat & 72.60 & 80.39 & 74.35 & 1.92 & 19.53 & 280.56 & -3.88 & 74.99 \\
\hline Black gram-wheat & 74.24 & 74.58 & 70.21 & 1.94 & 20.22 & 259.07 & -8.02 & 69.62 \\
\hline Rice- mung & 60.82 & 68.36 & 84.36 & 2.23 & 30.81 & 380.12 & 6.13 & 84.90 \\
\hline Maize -wheat & 75.06 & 86.32 & 76.25 & 1.88 & 27.90 & 278.28 & -1.98 & 77.46 \\
\hline Maize-cabbage & 57.53 & 87.69 & 79.12 & 1.90 & 173.37 & 376.76 & 0.89 & 80.97 \\
\hline Rice-cauliflower & 58.90 & 81.36 & 97.58 & 2.19 & 123.36 & 453.86 & 19.35 & 94.83 \\
\hline Pigeonpea-jute & 80.01 & 83.25 & 70.12 & 1.84 & 13.59 & 240.13 & -8.11 & 69.50 \\
\hline Chilly -wheat & 75.34 & 64.12 & 78.33 & 2.22 & 32.30 & 284.83 & 0.1 & 80.16 \\
\hline Rice-chilli & 57.53 & 66.39 & 70.14 & 2.05 & 36.14 & 334.00 & -8.09 & 69.52 \\
\hline Rice-potato & 77.26 & 90.36 & 83.69 & 1.92 & 121.33 & 296.99 & 5.46 & 84.40 \\
\hline Maize-mustard & 70.13 & 87.56 & 79.69 & 1.91 & 22.67 & 311.28 & 1.46 & 81.40 \\
\hline Rice -chickpea & 73.97 & 71.29 & 88.69 & 2.24 & 28.97 & 328.48 & 10.46 & 88.15 \\
\hline Rice- mustard & 73.69 & 84.25 & 71.33 & 1.84 & 23.16 & 265.16 & -6.9 & 71.07 \\
\hline Rice-wheat & 70.41 & 94.26 & 78.23 & 1.82 & 34.33 & 304.39 & - & 80.03 \\
\hline
\end{tabular}


(547.0 kg/ha) and rice - potato (521.3 kg/ha) sequence. The maximum removal of $\mathrm{N}$ may be attributed to greater biomass production of crops under these cropping systems [7]. The phosphorus and potassium uptake by different cropping system in a year was 41.2-130.2 kg P/ha and 210.0 - $698.3 \mathrm{~kg} \mathrm{~K} / \mathrm{ha}$, respectively. Amongst all cropping sequence maize - cabbage was found to the most exhaustive cropping system, which resulted in highest P (130.2 kg /ha) uptake and significantly superior to all the tested sequences. Further, least $\mathrm{P}$ uptake was reported with rice - mustard ( $41.2 \mathrm{~kg} / \mathrm{ha}$ ) and black gram - wheat ( $45.6 \mathrm{~kg} / \mathrm{ha})$ sequences and showed statistical similarity with each other. The highest removal of $\mathrm{K}$ was recorded in rice - potato $(698.3 \mathrm{~kg} / \mathrm{ha})$ sequence which, however, showed statistical parity with maize - cabbage (654.3 kg/ha) cropping system. Highest K uptake by rice - potato sequence was due to exhaustive nature of potato for $\mathrm{K}$ nutrient. Amongst all the tested sequences, least nutrient mining of major nutrient particularly $\mathrm{N}(299.3 \mathrm{~kg} / \mathrm{ha})$ and $\mathrm{P}$ (41.2 kg/ha) registered with rice-mustard sequence. However, least potassium mining recorded with rice-mung $(210.0 \mathrm{~kg} / \mathrm{ha})$ and was followed by pigeonpea-wheat $(232.6 \mathrm{~kg} / \mathrm{ha})$. Budgeting of the nutrients added as fertilizer and of those removed by the crops showed a deficit of nitrogen in pigeonpea-jute $(-222.3 \mathrm{~kg} /$ ha), rice - chickpea (-158.4 kg/ha) and rice - mung (-108.3 kg/ ha) cropping sequence (Table 3 ). This deficit was mainly due to lesser quantity of $\mathrm{N}$ applied to the legume crops and higher $\mathrm{N}$ concentration in the plant as well as higher biomass production. However, the other cropping system showed a negative balance of $\mathrm{N}$ in reasonable amount. Maize - mustard, followed by rice - mustard and pigeon pea - wheat cropping system showed the maximum positive balance of $\mathrm{N}$. The balance of $\mathrm{P}$ was positive in all the cropping system except maize-cabbage system, and it varied from 159.5 of chilly - wheat to $19.8 \mathrm{~kg} / \mathrm{ha}$ in rice cauliflower sequence. This shows that the $\mathrm{P}$ removed by the crops was less than that the applied to them. The maximum deficit of P - $14.8 \mathrm{~kg} / \mathrm{ha} /$ year was observed in maize -cabbage sequence, indicating that the quantity of $\mathrm{P}$ applied to crop was less than that removal from the soil. The highest gap between addition and removal was observed in potassium, which resulted in negative $\mathrm{K}$ balance in all the cropping systems. The maximum deficit of $\mathrm{K}(376.3 \mathrm{~kg} / \mathrm{ha} /$ year) was observed under maize cabbage, followed by rice - potato $(373 \mathrm{~kg} / \mathrm{ha} /$ year). Most of the observed crop sequence nutrient balance was in negative side ranging from -365.8 (maize-cabbage) to -97.7 (black gramwheat). These results indicate and alarming situation for mining of nutrients from soils, which requires a fresh look to revise them as per needs of the crops in the cropping system. However, this nutrient mining was quite low with maize - mustard sequence compared to all other tested system.

\section{Conclusion}

Thus, it was concluded that productivity, profitability and sustainable yield index were higher under rice - cauliflower and rice - mung cropping sequence then the traditional rice -wheat sequence. Further, overall nutrient mining by this system was quite low compared to other sequences which are practiced in this region.

Table 3: Nutrient removal and balance sheet of nutrient in different cropping system (pooled data of two years).

\begin{tabular}{|c|c|c|c|c|c|c|c|c|c|c|c|c|}
\hline \multirow[t]{2}{*}{ Cropping sequence } & \multicolumn{4}{|c|}{$\begin{array}{l}\text { Nutrient applied } \\
\text { (kg/ha) }\end{array}$} & \multicolumn{4}{|c|}{$\begin{array}{l}\text { Nutrient removed } \\
(\mathrm{kg} / \mathrm{ha})\end{array}$} & \multicolumn{4}{|c|}{$\begin{array}{l}\text { Nutrient balance in soil } \\
(\mathrm{kg} / \mathrm{ha})\end{array}$} \\
\hline & $\mathbf{N}$ & $\mathbf{P}$ & $\mathbf{K}$ & Total & $\mathbf{N}$ & $\mathbf{P}$ & $\mathbf{K}$ & Total & $\mathrm{N}$ & $\mathbf{P}$ & $\mathbf{K}$ & Total \\
\hline Pigeon pea-wheat & 350 & 180 & 221 & 751 & 422.3 & 76.9 & 232.6 & 731.8 & -72.3 & 103.1 & -11.6 & 19.2 \\
\hline Black gram-wheat & 332 & 175 & 177 & 684 & 336.3 & 45.6 & 399.8 & 781.7 & -4.3 & 129.4 & -222.8 & -97.7 \\
\hline Rice- mung & 180 & 220 & 102 & 502 & 288.3 & 68.9 & 210.0 & 567.2 & -108.3 & 151.1 & -108.0 & -65.2 \\
\hline Maize -wheat & 568 & 240 & 210 & 1018 & 608.3 & 99.6 & 468.3 & 1016.2 & -40.3 & 140.4 & -258.3 & -158.2 \\
\hline Maize-cabbage & 698 & 145 & 278 & 1121 & 702.3 & 159.8 & 654.3 & 1486.8 & -4.3 & -14.8 & -376.3 & -365.8 \\
\hline Rice-cauliflower & 523 & 125 & 102 & 750 & 473.3 & 105.2 & 456.3 & 1034.8 & 49.7 & 19.8 & -354.3 & -284.8 \\
\hline Pigeonpea-jute & 180 & 188 & 160 & 528 & 402.3 & 76.4 & 392.3 & 871.0 & -222.3 & 111.6 & -232.3 & -343.0 \\
\hline Chilly -wheat & 500 & 240 & 240 & 980 & 547.0 & 80.5 & 521.3 & 1148.8 & -47.0 & 159.5 & -281.3 & -168.8 \\
\hline Rice-chilli & 360 & 240 & 220 & 820 & 452.9 & 109.6 & 456.3 & 1018.8 & -92.9 & 130.4 & -236.3 & -198.8 \\
\hline Rice-potato & 630 & 240 & 325 & 1195 & 521.3 & 89.3 & 698.3 & 1308.9 & 108.7 & 150.7 & -373.3 & -113.9 \\
\hline Maize-mustard & 485 & 160 & 189 & 834 & 363.3 & 85.6 & 336.9 & 785.8 & 121.7 & 74.4 & -147.9 & 48.2 \\
\hline Rice -chickpea & 190 & 220 & 160 & 570 & 348.4 & 61.5 & 298.3 & 708.2 & -158.4 & 158.5 & -138.3 & -138.2 \\
\hline Rice- mustard & 412 & 150 & 152 & 714 & 299.3 & 41.2 & 301.2 & 641.7 & 112.7 & 108.7 & -149.2 & 72.25 \\
\hline Rice-wheat & 460 & 220 & 172 & 852 & 450.2 & 76.3 & 426.9 & 953.4 & 9.8 & 143.7 & -254.9 & -101.4 \\
\hline SEm \pm & & & & & 25.3 & 7.2 & 17.35 & 84.26 & & & & \\
\hline $\mathrm{CD}(\mathrm{P}=0.05)$ & & & & & 80.2 & 22.3 & 56.32 & 265.05 & & & & \\
\hline
\end{tabular}




\section{References}

1. Black CA, Evans DD, White JL, Ensminger LE, Clark FE. "Methods of Soil Analysis", Part I- Physical and Mineralogical Properties, Including Statistics of Measurement and Sampling. American Society of Agronomy. 1965:677.

2. Jackson, ML. Soil Chemical Analysis, Prentice Hall of India Pvt. Ltd. New Delhi, India, 1973 pp 183-204.

3. Kharub AS, Chauhan DS, Sharama, RK, Chhokar RS, Tripathi SC. Diversification of rice - wheat system for improving soil fertility and productivity. Indian Journal of Agronomy. 2003;48(3): 149-152.

4. Mukherjee D. Studies on profitability of efficient farming system in midhills situation of Eastern Himalaya. Journal of Farming System Research \& Development. 2012;18(1): 16-21.

5. Mukherjee D. Influence of integrated nutrient management on productivity, nutrient uptake and economics of maize (Zea mays) yellow sarson (Brassica rapa) cropping system under rainfed mid hill condition. Indian Journal of Agronomy. 2014;59(2): 221-228.

6. Mukherjee D. Nutrient and its management: Prospect and challenges under the changing environment scenario. In Advances in plant physiology. Vol. 15 (eds. Hemantaranjan, A.). Scientific Publishers, Jodhpur, India. 2014:413-442.

7. Mukherjee, D. Food security: A world wide challenge. Research and Review: Journal of Agriculture and Allied Sciences. 2015;4(1): 3-5.

8. Mukherjee D. Integrated nutrient management practices for enhancing blackgram (Vigan mungo L. Hepper) production under mid hill situation in North Eastern Himalaya. Journal of Food Legumes. 2015;28(1): 83-85.

9. Singh NB, Verma KK. Production potential and economics analysis of rice (oryza sativa) -based cropping system. Indian Journal of Agronomy. 1998;43(2): 199-203.

10. Vittal KPR, Maruthi GR, Singh HP, Samra JS. Sustainability index. In: Sustainability of Practices of Dryland Agriculture: Methodology and Assessment, Central Research Institute for Dryland Agriculture, Hyderabad. 2002: 4-9.

11.Yadev DS, Newaj R. Studies on increasing the utilization of natural resources through intensive cropping system. Indian Journal of Agronomy. 1990;35 (1\&2): 50-55. 